\title{
Primary synovial chondromatosis of the ankle joint presenting as monoarthritis
}

\author{
Tânia Santiago, Cura Mariano
}

Centro Hospitalar e Universitário de Coimbra, Coimbra, Portugal

\section{Correspondence to}

Tânia Santiago,

tlousasantiago@hotmail.com

\section{DESCRIPTION}

Synovial chondromatosis is a rare, benign condition characterised by the formation of multiple cartilaginous and osteocartilaginous bodies in the capsule. ${ }^{1}$ Synovial chondromatosis has been widely described in the literature. ${ }^{1-3}$ Most cases involve temporomandibular, shoulder, elbow, hip and knee joints. Interestingly, published cases with ankle joint involvement are uncommon. The rarity of this diagnosis in the literature spurred us to report our case of synovial chondromatosis of the ankle joint.

The patient, a 42-year-old man, had a 2-week history of pain and swelling in his left ankle. On physical examination he had a decreased range of motion on dorsiflexion and in inversion/eversion of the ankle. A radiograph revealed soft tissue oedema surrounding multiple calcified loose bodies located at the anterior aspect of the left ankle (figure 1A). Because there was no history of direct ankle trauma or systemic inflammatory disease, primary synovial chondromatosis was strongly suspected. The patient underwent arthrotomy and surgical excision of the intra-articular bodies, and the diagnosis was confirmed (figure 2A-C). Histological examination revealed synovial chondromatosis with multiple
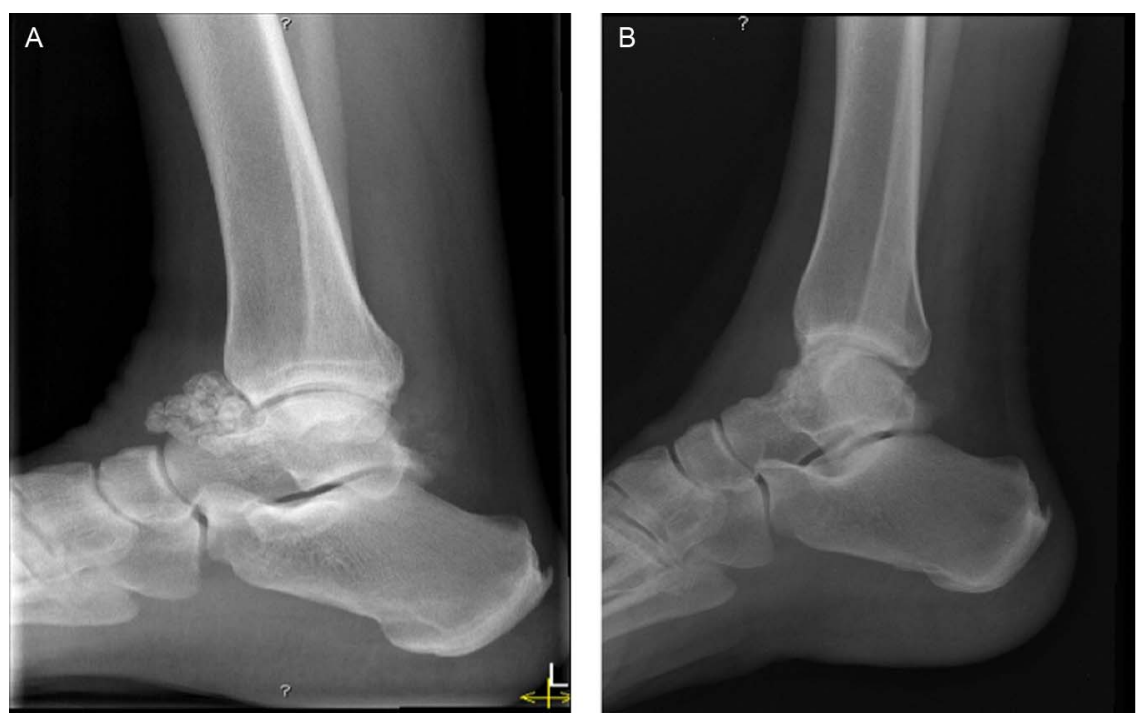

Figure 1 (A) Notable well-circumscribed multiple calcified nodules anteriorly on radiograph of the left ankle; (B) four months postoperatively. ginous bodies in the capsule.

\section{Learning point} of joints, bursae or tendon sheaths.

\section{Competing interests None.}

Patient consent Obtained. reviewed. osteocartilaginous fragments from the synovium. At 4 months postoperatively, the patient is asymptomatic with no evidence of recurrence on serial physical examination and radiography (figure 1B). Synovial chondromatosis is a rare, benign condition characterised by the metaplasia of synovial tissue and the formation of cartilaginous and osteocartila-

Primary synovial chondromatosis represents an uncommon benign disorder with metaplasia of the subsynovial connective tissue with formation of cartilaginous bodies within the synovial membrane

Provenance and peer review Not commissioned; externally peer

To cite: Santiago T, 

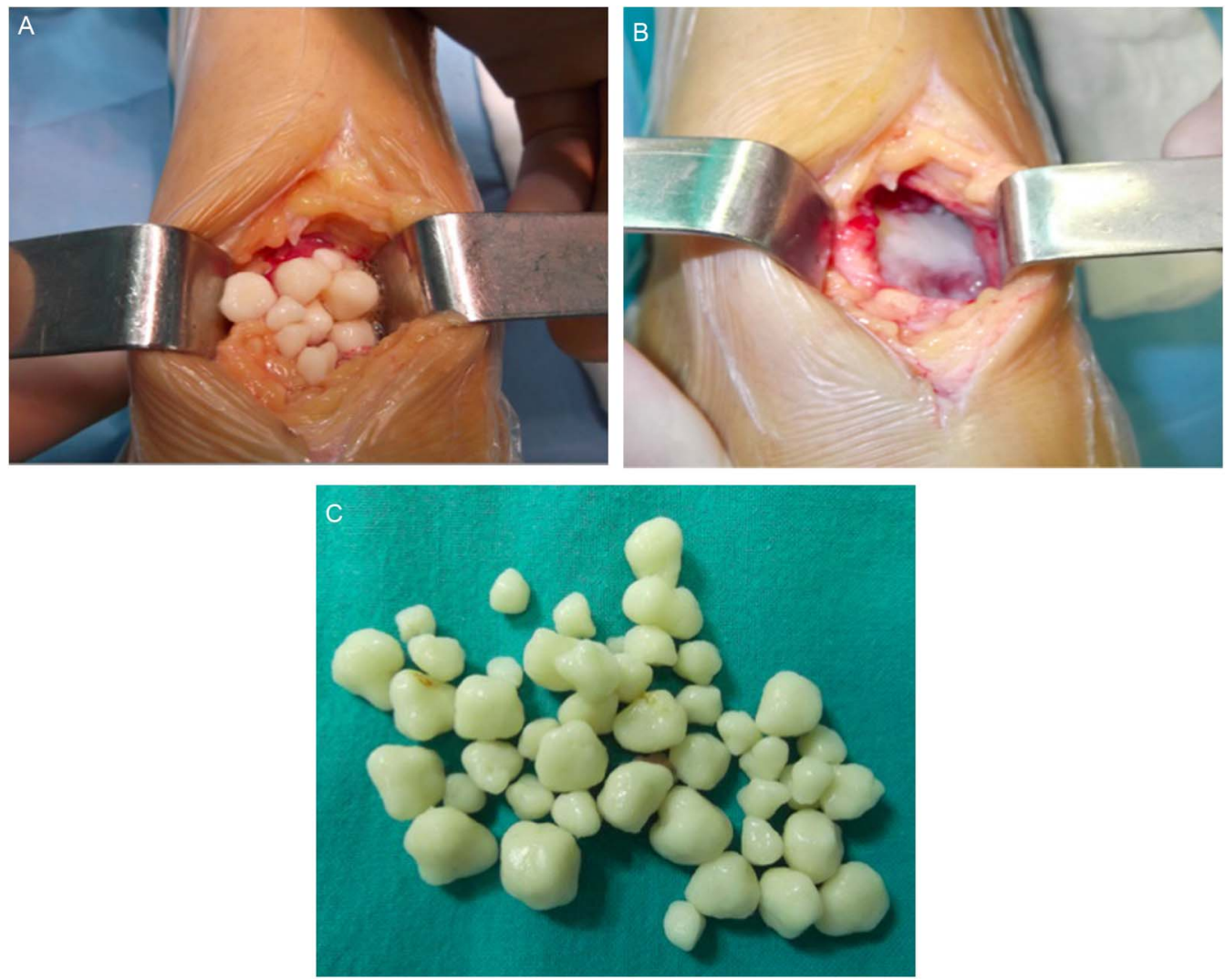

Figure 2 (A) Intraoperative view of the lesion and (B) excised loose bodies. (C) Osteocartilaginous bodies removed from ankle joint.

\section{REFERENCES}

1 Wiedemann NA, Friederichs J, Richter U, et al. Secondary synovial chondromatosis of the ankle joint. Orthopade 2011;40:807-11.

2 Brodsky JW, Jung KS, Tenenbaum S. Primary synovial chondromatosis of the subtalar joint presenting as ankle instability. Foot Ankle Int 2013;34:1447-50.

3 Murphey MD, Vidal JA, Fanburg-Smith JC, et al. Imaging of synovial chondromatosis with radiologic-pathologic correlation. Radiographics 2007;27:1465-88.

Copyright 2013 BMJ Publishing Group. All rights reserved. For permission to reuse any of this content visit http://group.bmj.com/group/rights-licensing/permissions.

BMJ Case Report Fellows may re-use this article for personal use and teaching without any further permission.

Become a Fellow of BMJ Case Reports today and you can:

- Submit as many cases as you like

- Enjoy fast sympathetic peer review and rapid publication of accepted articles

- Access all the published articles

- Re-use any of the published material for personal use and teaching without further permission

For information on Institutional Fellowships contact consortiasales@bmjgroup.com

Visit casereports.bmj.com for more articles like this and to become a Fellow 